\title{
Traditional Factors of Eclectic Paradigm, Doing Business and Chinese ODI
}

\author{
Yali Wang \\ School of Economic and Management \\ Shandong Youth University of Political Science \\ Jinan, China \\ wyljn08125@163.com
}

\begin{abstract}
This research tries to identify the key host countrylevel factors playing important roles when Chinese firms conduct overseas activities, using a survey of Chinese 284 listed companies between 2001 and 2015. Via Poisson model, three-dimensional analysis (host country's development status, firms' ownership and industry category) are carried out to investigate the impact of traditional factors of eclectic paradigm and doing business index on ODI decisions. The results suggest that Chinese firms' locations are positively associated with larger host demand, richer resource endowment, more relevant patents and favorable doing business. In addition, the key factors vary for different development status, firms' ownerships and industry categories. These findings do have important policy implications.
\end{abstract}

Keywords-Chinese MNEs; ODI; eclectic paradigm; doing business

\section{INTRODUCTION}

Despite the complicated economic situation and faltering world economic recovery during 2012, China's economy has maintained steady growth. Chinese Government has speeded up the implementation of "going global" strategy, vigorously promoted foreign investment facilitation, and actively encouraged qualified enterprises of different kinds of ownerships to conduct foreign investment, thus led to enterprises' increasing internal motivation to integrate into economic globalization. According to 2015 Statistical Bulletin of China's Outward Foreign Direct Investment, China's outward foreign direct investment (ODI) net flows in 2015 reached \$87.8 billion, increased by $17.6 \%$ compared to 2011 .

The dramatic growth and bright prospects of China's ODI have attracted considerable attentions from scholars at home and abroad. A number of studies have examined a series of issues regarding China's ODI, including ODI motives and performance implication ${ }^{[4]}$ (e.g. Agyenim, Wang, \&Yang, 2008; Athreye and Kapur, 2009; Deng, 2004, 2009), ODI patterns and entry mode choice ${ }^{[3]}$ (Buckley et al, 2008; Cui and Jiang, 2009, 2010, \&2011) and the determinants and driving force of Chinese firm's involvement in overseas investment activities ${ }^{[2]}$ (Buckley et al, 2007; Chou, Chen, and Mai, 2011). However, the issue of ODI location choice, one of the most crucial decisions that MNEs need to make in their internationalization process, has not received much attention. Most research on location choice only focus on the FDI from developed economies, less is understood about the emerging market, such as China. From the firm heterogeneity,
Ramasamy (2015) and Duanmu ${ }^{[5]}$ (2015) compared the reactions of SOEs (State-Owned MNEs) and non-SOEs to host country factors and found that the determinants of internationalization differ based on ownership. Kang and Jiang (2015) concluded that traditional economic factors of host countries have a major role to play in affecting Chinese MNEs’ ODI location choices. Quer, Claver and Rienda (2015) investigated the role of host country variables and found that political risk and culture distance do not have strong association with the location of Chinese ODI.

Responding to the research gap, this study aims to make complement to the literature by investigating the determinants influencing Chinese MNEs from three levels: host country's development status, MNE's ownership and industry category.

The structure of remaining paper is organized as follows. The insights from the previous empirical literature are presented in section 2. Based on eclectic paradigm and doing business perspective, we propose a series of hypotheses in section3. We then test these hypotheses using data of listed companies and give the results and discussion. In sector 6 , we conclude by suggesting possible avenues for future research.

\section{HYPOTHESES DEVELOPMENT}

In this section, we develop hypotheses of host country features influencing ODI location decision of Chinese enterprises from the respective of country, industry and ownership structure. Rooted in the eclectic paradigm of Dunning, we classified factors to market-seeking, resourceseeking, strategic asset-seeking and doing business.

An increasing number of empirical studies prove that economic factors related to the host market are the most widely tested variables influencing FDI location choices (Bevan and Estrin,2004). In case of China's ODI, recent studies suggest that market seeking is one of the major driving forces for Chinese firms ${ }^{[1]}$ (Buckley et al., 2007, 2008; Deng, 2004). The larger market size and domestic demand will reduce the costs and increase the possibility of scale economies involving mass production. Increasing intense of intratype competition in home country and the ambitions to develop new market and brand awareness have been responsible for a large proportion of Chinese market-seeking ODI. 
Hypothesis 1: The choice of Chinese firm's ODI location is positively associated with the large host market, regardless of the firms' characteristic.

Rich natural resources of host economy is not only the important factor of attracting foreign investment, but also the principal motive of FDI and core requirement of conducting backward vertical integration (Dunning,1993). As China's per capita share of natural resources below the average, firms are more willing to invest in the economies rich in natural resources. The factors of several high-profile Stated-owned enterprises (SOEs) in China give the powerful proof that firms are more willing to invest in the economies rich in natural resources (Deng, 2009; Cheng and Ma, 2009). Compared to POEs, SOEs have more financial supports to conduct M\&As. Nevertheless, natural resource endowment still is the absolute key consideration when private mining firms invest overseas.

Hypothesis 2a: The richer host country resources endowment is, the greater the chance of Chinese enterprises for its direct investment regardless of the development level of the country.

Hypothesis 2b: SOEs are more attracted to the countries with large natural resource than POEs did.

Hypothesis 2c: For the terms of industries, mining firms are more attracted to the countries with large natural resource than manufacturing and service firms.

According to the resource-based theory (RBT), a firm's strategic assets determine its competitive advantage and performance, which are accessed by the most effective channel of FDI and M\&A. Strategic asset include reputation, buyer-supplier relationships, tacit knowledge, R\&D capability, brand name and proprietary technologies. In addition, China is the only Asian government that not only actively facilitates and encourages outward FDI but also specifically encourages investment in $\mathrm{R} \& \mathrm{D}$ to enhance innovative capability (UNCTAD, 2005). So Chinese firms mostly consider relevant patent standing for strategic assets as the necessary factor when involve multinational activities.

Hypothesis 3a: Chinese strategic asset-seeking firms are more likely to invest in developed economies than developing countries.

Hypothesis 3b: Comparing with SOEs, Chinese POEs higher depend on strategic assets.

Hypothesis 3c: Chinese companies pursuing strategic asset mostly concentrated in the service sector, followed by manufacturing, last is the mining sector.

Doing business report, published by World Bank was the first document aiming to provide relevant knowledge and improve the quality of rules constrained on the private firms' activities. Via tracking the progress made by each economy during the process of establishing well business environment, it is more and more important to promote global prosperity and create more opportunities for POEs, especially for middle and small-sized enterprises. And we can reach a consensus that POEs are more likely to invest in host countries with favorable doing business environment than SOEs.
Hypothesis 4a: Chinese firms are more likely to invest in developed countries with higher ranking and developing countries of lower ranking.

Hypothesis 4b: POEs are more likely to invest in host countries with favorable doing business environment than SOEs.

Hypothesis 4c: Firms of service and manufacturing industry are more likely to invest in host countries with favorable doing business environment than mining firms.

\section{DATA AND METHOD}

The sample of this study is based on 597 ODI projects made by the mainland 284 Chinese listed companies in 55 economies (54 countries and Hong Kong) between 2001 and 2015 obtained from Z-database and Reuters database. We considered only already conducted FDIs, thus excluding deals and bids not confirmed. In order to enhance data reliability, we carefully check each item of FDI, including each company's website and the main "cross-border M\&A deals" listed report annually by the UNCTAD World Investment Report.

We explain our dependent, independent and control variables as follows. Our dependent variable is label as frequency count of Chinese ODI projects in the host economy. Table II is our country level independent variables. In addition, development status of the host country can be obtained from the World Bank. Ownership and the industry characteristic of the enterprises are gained from the company introduction of technical trading software. All the country level variables are one year lagged.

Our research is based on the Poisson regression model, given that every observed value follows the Poisson distribution. The model is given as:

$$
P\left(y_{i} \mid X_{i}, \beta\right)=\frac{e^{-m\left(X_{i}, \beta\right)} m\left(X_{i}, \beta\right)^{y_{i}}}{y_{i} !}
$$

Where, $y_{i}$ is the number of Chinese ODI projects in country $i$ during the specific period; $X_{i}$ is the explanatory variable defined in Table 1 and $\beta$ is the parameter to be estimated by the following equation:

$$
E\left(y_{i} \mid X_{i}, \beta\right)=\operatorname{var}\left(y_{i} \mid X_{i}, \beta\right)=m\left(y_{i} \mid X_{i}, \beta\right)=e^{X_{i} \beta}
$$

Maximum likelihood estimator $\hat{\beta}$ will be consistency, validity and obey normal distribution unless conditional mean be correctly assigned and conditional distribution of $y$ following Poisson distribution.

Poisson model is fitted for the sample data and for each subgroup (developed and developing counties; SOE and POE; mining, manufacturing and services). 
TABLE I. LISTS OF VARIABLES

\begin{tabular}{|l|l|}
\hline & Proxy for \\
\hline FDI & $\begin{array}{l}\text { Frequency count of Chinese ODI projects in the host } \\
\text { economy }\end{array}$ \\
\hline GDP & Host country's GDP (US dollar, constant) \\
\hline GDPG & Host country's GDP growth \\
\hline DEMAND & Expense (\% of GDP) \\
\hline ENERGY & Energy imports, net (\% of energy use) \\
\hline PATENT & Patent applications, nonresidents \\
\hline BUSINESS & $\begin{array}{l}\text { Ease of doing business index (1=most business-friendly } \\
\text { regulations) }\end{array}$ \\
\hline OPENNESS & FDI net flow (\% of GDP) \\
\hline INFLATION & Host country's rate of inflation \\
\hline BILTRADE & $\begin{array}{l}\text { The percent of trade volume between China and host } \\
\text { country }\end{array}$ \\
\hline
\end{tabular}

TABLE II. SAMPLE DETAILS

\begin{tabular}{|c|c|c|}
\hline & & No. ODI projects \\
\hline \multirow{4}{*}{ Regional distribution } & Asia & 177 \\
\cline { 2 - 3 } & Latin America & 15 \\
\cline { 2 - 3 } & Europe & 165 \\
\cline { 2 - 3 } & Africa & 9 \\
\cline { 2 - 3 } & North America & 157 \\
\cline { 2 - 3 } & Oceania & 74 \\
\hline Host country's & Developed countries & 487 \\
\cline { 2 - 3 } development level & Developing countries & 110 \\
\hline MNE's ownership & POEs & 226 \\
\cline { 2 - 3 } & SOEs & 371 \\
\hline \multirow{3}{*}{ Industry category } & Mining firms & 205 \\
\cline { 2 - 3 } & Manufacturing firms & 183 \\
\cline { 2 - 3 } & Services firms & 141 \\
\cline { 2 - 3 }
\end{tabular}

TABLE III. MODELING RESULTS

\begin{tabular}{|l|l|l|l|l|l|l|l|l|}
\hline Variable & Full sample & $\begin{array}{l}\text { Developed } \\
\text { economies }\end{array}$ & $\begin{array}{l}\text { Developing } \\
\text { economies }\end{array}$ & SOE & POE & Mining & Manufacturing & Services \\
\hline GDP & $0.311073^{* * *}$ & $0.457623^{* * *}$ & -0.050023 & $0.236175^{* * *}$ & $0.434681^{* * *}$ & 0.116903 & $0.216624^{* * *}$ & $0.436395^{* * *}$ \\
\hline GDPG & 0.001765 & -0.014038 & $0.096608^{* *}$ & 0.007268 & -0.005817 & -0.002251 & 0.007719 & 0.001232 \\
\hline DEMAND & $0.167453^{* *}$ & $0.354332^{* * *}$ & $0.463244^{* * *}$ & $0.228073^{* *}$ & $0.154497^{*}$ & $0.085931^{*}$ & $0.074274^{*}$ & $0.342825^{* * *}$ \\
\hline ENERGY & $-0.172967^{* * *}$ & $-0.260405^{* * *}$ & $-0.230326^{* * *}$ & $-0.221722^{* * *}$ & $-0.089781^{*}$ & $-0.273053^{* * *}$ & 0.003608 & 0.029223 \\
\hline PATENT & $0.008029^{* * *}$ & $0.027774^{* * *}$ & $-0.022133^{*}$ & $0.004479^{* * *}$ & $0.047603^{* * *}$ & 0.02003 & $0.013162^{* * *}$ & $0.019014^{* * *}$ \\
\hline BUSINESS & $-0.18211^{* * *}$ & $-0.421827^{* * *}$ & $0.71484^{* * *}$ & $-0.13904^{* * *}$ & $-0.234751^{* * *}$ & $-0.192777^{* *}$ & $-0.236188^{* * *}$ & $-0.299001^{* * *}$ \\
\hline INFLATION & -0.013518 & $-0.174191^{* * *}$ & $0.009868^{* * *}$ & $-0.030979^{*}$ & -0.010822 & $-0.056746^{*}$ & -0.002289 & 0.015369 \\
\hline OPENNESS & $2.404661^{* * *}$ & $4.473171^{* * *}$ & -3.502034 & $2.847795^{* * *}$ & $2.61459^{*}$ & -1.161796 & $-0.934677^{* *}$ & $1.782112^{* *}$ \\
\hline BILTRADE & $1.609309^{* * *}$ & -0.020103 & 0.804613 & $1.773703^{* * *}$ & 0.055142 & $1.071049^{*}$ & -0.226102 & 0.740073 \\
\hline
\end{tabular}

\section{Modeling Results AND Discussion}

Quite similar results can be obtained from Poisson model and Negative Binomial model. Our final interpretation is based on the Poisson model (see Table III) with overall lower likelihood rate. In general, the estimated coefficients for the various models reveal that the criteria for choosing investing locations among firms with different destination, ownerships and industrial characteristic are not the same.

For the host market variable, our results on the whole accept $\mathrm{H} 1$ that the choice of Chinese firm's ODI location is positively associated with the host domestic market. Firstly, the coefficient of GDP is significant positive in any model excepting the model of developing economies with an even surprising negative insignificant sign (-0.050023). China being the biggest developing country in the world, Chinese firms are more likely to less-developed developing countries to expand the new market and high global market share. While for the variable of GDP growth, it is turned out to be insignificant connection with location decisions as all the coefficient is insignificant except the model of developing economies. And for the variable of host demand, it firmly supports $\mathrm{H} 1$ as the coefficients are significant positive in any model. Comparing the three type industrial firms, domestic demand play the most important role when services firms conduct multinational activities, next is mining and manufacturing firms are last $(0.342825>0.085931>0.074274)$.

For the energy variable, our empirical results confirm that Chinese firms are indeed attracted to natural resource rich economies and the coefficient is significant negative in all models except the model of manufacturing and services industries. Due to -260405 (coefficient in developed countries)and -0.230326 (coefficient in developed countries) with little difference, this consist with $\mathrm{H} 2 \mathrm{a}$ that the richer host country resources endowment is, the greater the chance of Chinese enterprises for its direct investment regardless of the host country's development status. On the firms' ownership, the results strongly confirm $\mathrm{H} 2 \mathrm{~b}$ that SOE tend to be attracted to the countries with rich natural resource, this tendency is absent in POE $(|-0.221722|>|-0.089781|)$. In addition, with insignificant coefficient in model of manufacturing and services industries, we believe that mining firms are more attracted to the countries with large natural resource as H2c stated.

For the patent variable, our results also accept that Chinese firms are strategic asset motivating to improve their competitive disadvantages in innovation and technology, as the coefficients are positive excluding the model of developing countries with negative value and mining with insignificant value. Firstly, as H3a stated, Chinese strategic 
asset-seeking firms are more likely to invest in developed economies than developing countries as $|0.027774|>\mid$ 0.022133|. The negative sign in developing countries model perhaps be caused by the fact that China is the biggest developing countries in the world. Secondly, consistent with H3b, Chinese POEs higher depend on strategic assets than SOEs (0.047603>0.004479). Lastly, comparing the value of three types of industry, we can conclude that service sector tend to be attracted with more strategic assets than manufacturing sector $(0.019014>0.013162)$ and mining firms' location decision may have nothing with the patent variable as the coefficient (0.02003) is insignificant. And the example of Geely Automobile merging VOLVO and Lenovo merging IBM PC further proved that strategic asset-seeking firms are concentrated in POEs and manufacturing and service sectors.

For the business variable, the result of significant negative coefficient in majority of models means that Chinese firms are attracted to the countries with favorable business environment. The significant negative value $(-0.421827)$ in the developed model and significant positive value $(0.71484)$ in the developing model supply the new phenomenon that Chinese firms are more likely to invest in developed countries with higher ranking and developing countries of lower ranking as H4a stated. At the same time, our empirical results confirm H4b that POEs are more likely to invest in host countries with favorable doing business environment than SOEs (|$0.234751|>|-0.13904 \mid)$ consistent with the original reason of establishing this index. Our results also test $\mathrm{H} 4 \mathrm{c}$ that service and manufacturing sectors are more likely to invest in more favorable doing business environment than mining firms (|$0.299001|>|-0.236188|>|-0.192777 \mid)$.

\section{CONCLUSIONS}

The main empirical contribution of our research lies in having providing new evidence regarding three levels of country, ownership and industry. We try to identify the key country-level factors playing an important role during Chinese firms conducting overseas activities. The results show that the key factors influencing location choice of Chinese multinationals are greatly different from different country's development level, firms' ownership and industry characteristic.

There are several interesting avenues for further research. Based on the framework, it will also be interesting to study the interaction of the above three levels, such as what is the key factor when the Chinese mining POEs merging the enterprise of developed countries? Such researches will be continued.

\section{REFERENCES}

[1] Buckley, P. J., Clegg, L. J., Cross, A. R., Liu, X., Voss, H., \& Zheng, P. The determinants of Chinese outward foreign direct investment. Journal of international business studies,2007, 38(4), 499-518.

[2] Chen, Y. Y., \& Young, M. N. Cross-border mergers and acquisitions by Chinese listed companies: A principal-principal perspective. Asia Pacific Journal of Management, 2010, 27(3), 523-539..

[3] Cui, L., \& Jiang, F.. Behind ownership decision of Chinese outward FDI: Resources and institutions. Asia Pacific Journal of Management, 2010, 27(4), 751-774.

[4] Deng, P. Outward investment by Chinese MNCs: Motivations and implications. Business Horizons, 2004, 47(3), 8-16.

[5] Duanmu, J. L. Firm heterogeneity and location choice of Chinese Multinational Enterprises (MNEs). Journal of World Business, 2015, 47(1), 64-72. 